\title{
Investment Banking Relationships and Merger Fees ${ }^{*}$
}

\author{
Anthony Saunders \\ John M. Schiff Professor of Finance \\ \& Chairman, Department of Finance \\ Stern School of Business \\ New York University \\ Anand Srinivasan \\ Assistant Professor of Finance \\ Terry College of Business \\ University of Georgia
}

October 2001

\footnotetext{
* We would like to thank Yakov Amihud, Ken Froewiss, William Greene, Kose John, Jim Linck, Loretta Mester, Jeff Netter, Gerald Rosenfeld, A.R. Radhakrishnan, Jayanthi Sunder and David Yermack for their comments. We would also like to thank seminar participants at Baruch College, Case Western Reserve, Fordham University, London Business School, New York University, Texas Christian University, Penn State, University of Georgia, University of Iowa and University of Notre Dame. Any errors that remain are solely our responsibility. Please address correspondence to Anthony Saunders, KMEC 9-190, Dept of Finance, Stern School of Business, New York University, New York, NY 10012 or send e-mail to asaunderestern.nyu.edu.
} 


\begin{abstract}
This paper is among the first to investigate the effect of a prior investment banking relationship on merger advisory fees paid by acquiring firms. We find that acquiring firms pay a higher fee to advisors when they have had a continuing relationship and a lower fee when they switch to an advisor with whom they have had no prior relationship. We develop a measure of relationship strength between an acquiring firm and its merger advisor based on previous debt, equity and merger transactions completed by the acquiring firm. We also examine the relationship between a merger advisor's reputation and its ability to retain clients. We find that firms are more likely to switch if their $\mathrm{M}$ and $\mathrm{A}$ advisor is not a top tier investment bank. To test if higher fees are compensation for better performance, we examine differences between the average announcement returns of acquiring firms that switch advisors and those that do not. We find no significant difference between these two return samples. Overall, our findings indicate that acquiring firms perceive benefits of retaining merger advisors with whom they have had a prior relationship (even at the cost of higher fees) and/or they face some other (higher) costs of switching to new bank advisors.
\end{abstract}




\section{Introduction}

While previous studies have looked at various factors impacting (cross-sectionally) merger advisory fees, little attention has been paid to the inter-temporal relationship among M and $\mathrm{A}$ advisors and client firms. ${ }^{1}$ In particular, does a long-term relationship developed between an acquiring firm and an advisory firm (e.g. investment bank) result in higher or lower $\mathrm{M}$ and $\mathrm{A}$ fees? ${ }^{2}$ Further, does a long-term relationship get rewarded in the capital market by the acquirer earning higher abnormal returns on a merger announcement compared to the case where the acquirer has had no previous relationship with the advisor or has switched to a new advisor.

Using a measure of advisor relationships based on prior transactions completed by a client firm with an advisor (henceforth investment bank) we find that: (i) acquiring firms pay a higher fee to advisors with whom they have had a long-term relationship and (ii) these higher fees are not rewarded by higher abnormal returns for such firms on $\mathrm{M}$ and $\mathrm{A}$ announcements. Overall, these results are consistent the existence of either switching costs and/or other benefits arising from continuing investment banking relationships - such as better service and derived relationship certification benefits. Indeed, we find that a client is more likely to switch when the $\mathrm{M}$ and $\mathrm{A}$ advisor is not a top tier investment bank (i.e. has a lower reputation).

Section 2 of the paper provides an overview of the merger advisory market and describes the sample and variables used. Section 3 describes the hypotheses and empirical tests. Section 4 presents a summary and conclusion.

\footnotetext{
${ }^{1}$ Hunter and Walker (1990), McLaughlin $(1990,1992)$ and Rau (2000) among others.
} 


\subsection{Overview of the US M and A Market}

The merger advisory market is an important source of revenue for most large investment and commercial banks in the United States. In 1998, M and A transactions amounted to over $\$ 800$ billion with merger advising accounting for as much as $40 \%$ of the total combined revenue obtained from merger advising and public underwriting of some top investment and commercial banks (See Table 1). Entry into this market has never been subject to significant regulatory barriers. In particular, while the Glass-Steagall Act (prior to 1999) inhibited commercial banks' provision of underwriting services, no such barrier inhibited their provision of $\mathrm{M}$ and $\mathrm{A}$ advisory services.

Table 2 provides a list of the top 10 advisors (based on market share) for mergers between public companies in the U.S. for each year from 1985 to 1998. First, a striking feature is that most of the top 10 advisors are "traditional" investment banks and not commercial banks. This changes towards the end of the sample period when J.P. Morgan, Chase Manhattan and NationsBank were among the top 10 advisors. Second, there appears to be considerable persistence in market share. For example, Goldman Sachs and Morgan Stanley are in the top 5 throughout the sample period. Third, most of the top merger advisors are also top underwriters. Many of the banks listed in Table 2 also have a high ranking in the underwriting reputation tables of Carter, Dark and Singh (1998). ${ }^{3}$

\footnotetext{
${ }^{2}$ James (1992) looks at prior underwriting relationships and investment banking fees while Nanda and Warther (1998) and Krigman, Shaw and Womack (2000) study switching behavior in the public issue underwriting markets. By contrast, our paper focuses on selection and switching issues in the market for $\mathrm{M}$ and A services.

${ }^{3}$ Each year, there was a small fraction of the merger transactions where neither the target nor the acquirer used an advisor. However, the vast majority of companies involved in merger transactions use advisors.
} 


\subsection{Sample selection}

The sample of mergers used for this study were obtained from the Security Data Company (SDC) database of mergers and new capital issues. The SDC database has a record of new public issues, from 1970, and a record of merger transactions from 1979. We select all mergers and tender offers that were successfully completed for which information on total advisory fees paid by the acquiring firm were available. ${ }^{4}$ Importantly, these total fees (as defined by SDC) do not include fees paid for any bridge loan financing or fees paid for any subsequent debt or equity issues used to finance the merger. ${ }^{5}$

We include in our sample those mergers announced and completed over the Jan 1, 1985 to Oct 1, 1998 period. ${ }^{6}$ SDC defines a "merger" as a transaction where the acquiring firm owned less than $50 \%$ of the target before the transaction and owned $100 \%$ of the target at the end of the transaction.

Of these mergers, we chose transactions where the acquiring firm had stock price data on the CRSP database one month prior to the announcement of the merger transaction. The matching with the CRSP database was done using the cusip symbol of the acquiring firm. This matching resulted in a sample of 817 mergers. Using this list of cusips, we went back to the SDC database and recorded all debt, equity and merger transactions that were completed by the acquiring firm in the four years prior to the merger transaction. These data were used to establish measures of relationship strength between the $\mathrm{M}$ and $\mathrm{A}$ acquirers and their advisors.

\footnotetext{
${ }^{4}$ Henceforth, we shall collectively refer to mergers and tender offers as mergers.

${ }^{5}$ We excluded target firms for the very reason that we are concerned about the effects of long-term relationships and $\mathrm{M}$ and $\mathrm{A}$ fees and targets cease to exist on an $\mathrm{M}$ and A completion. We also excluded LBO's from the sample.

${ }^{6}$ The reason for starting in 1985 (and not 1979, which is the year that the merger database starts) is as follows: To properly calculate the measure of relationship strength, one needs data on all prior debt, equity and merger transactions. Since merger data begins only from 1979, the earliest we can begin is 1983 . However, the
} 
Specifically, we define prior relationships to include prior debt and equity underwriting for the acquiring firms as well as provision of $\mathrm{M}$ and $\mathrm{A}$ services within a time period of four years before the announcement date of the transaction. ${ }^{7}$ This resulted in 656 mergers for which the acquiring firm had at least one transaction in the four years preceding the announcement date of the merger. Of these, there were 45 transactions where the only role of the advisor was to provide a fairness opinion. Since this is a relatively minor role (see McLaughlin (1992)), we exclude these transactions. The resulting sample of 611 transactions formed our base sample. Company specific data were obtained using the SDC database and the CRSP database. Due to the long time period over which this study extends, we convert all nominal dollar values into real values for the year 1998 using the chain weighted GDP deflator. $^{8}$

We employ the log of total fees (total compensation for advisory services) as well as total fees paid as a percentage of transaction value as alternative measures of the dependent variable.

\subsection{Construction of Reputation and Relationship measures}

Table 3 describes the variables used in the empirical analysis in Sections 3 and 4. In this sub-section, we describe in detail the construction of the variables used to proxy for $\mathrm{M}$ and $\mathrm{A}$ advisor reputation, relationships and switching.

robustness checks of the relationship strength measure use up to 6 years of data on prior merger transactions. This implies that the earliest we can start is 1985. In any case, availability of fee data in this period is sparse.

${ }^{7}$ There is nothing sacrosanct about this time period. In one of the robustness checks, we define relationships based on shorter and longer time periods. These do not alter the results. The choice of four years was dictated by balancing sample size (short duration implies fewer companies would satisfy the requirement of having a transaction within the time period) versus relationship continuity (how much of a relationship do you really have if you have had no transactions in many years?)

${ }^{8}$ The results change very little if nominal values are used. 


\subsubsection{Reputation of Advisor}

We use the tier of an advisor, based on its market share of total M and A transactions as the proxy for reputation. Market share of an advisor in any given year is defined as the ratio of the total dollar value of all successful mergers in that year where the given advisor was retained by the acquiring firm to the total dollar value of all successful mergers in the same year. In merger transactions where more than one advisor was retained, all advisors are given full credit for the deal.

In the event of a merger between two advisors (banks), the market share of the combined entity is set equal to the sum of the market shares of the two individual banks. For example, in the computation of market share of Bankers Trust (BT) and Wolfensohn after their 1996 merger, the market share of BT Wolfensohn in the year subsequent to the completion of their merger would be the sum of the market shares of BT and Wolfensohn in the previous year.

The market share of a bank (lagged by one year) is used to classify each advisor into one of three possible reputational tiers. Banks that rank from 1 through 5 (i.e. in the top 5) are classified as top tier, banks that rank from 6 through 20 are classified as middle tier, and banks below this are classified as bottom tier. For transactions where multiple advisors were retained, the tier of the advisor with the largest market share is used in the empirical analysis. ${ }^{9}$

\subsubsection{Relationship Strength}

One needs to identify a reasonable time frame for the measurement of relationships. As described above, the relationship time frame is chosen as four years. Thus, all references

\footnotetext{
${ }^{9}$ Use of market share as a proxy for reputation is justified by Megginson and Weiss (1991). They document that reputation measures based on market share have a high correlation with the ranking of Carter and Manaster (1990)
} 
to prior transactions in this paper should be read as transactions completed by the acquiring firm in the four years prior to the announcement of the merger transaction. Krigman, Shaw and Womack (2000) use a three-year time period for studying underwriting relationships and Nanda and Warther (1998) use a five-year time period for measuring underwriting relationships. In robustness checks of our results, we varied the time period used to define relationships with little effect on the regression results.

Relationship strength is thus defined as the ratio of two values. The denominator is the total dollar value of all transactions of debt, equity and mergers completed by the acquiring firm over the past four years. ${ }^{10}$ The numerator is calculated as the sum of the following. The merger advisor is given full credit (in \$ terms) for any capital raising issue where it was retained as a lead manager by the acquiring firm, and any prior mergers where it was retained in an advisory capacity over the previous four years. For any public issue where the given merger advisor was retained as a manager, but not as the lead manager, it is given $50 \%$ of the credit (in $\$$ terms). ${ }^{11}$ This relationship strength measure will always lie between zero and one. A value of one indicates the strongest possible relationship and a value of zero indicates no relationship. The bank that has the highest relationship strength with the acquiring firm is defined as its lead bank. ${ }^{12}$

\footnotetext{
${ }^{10}$ The current merger transaction is excluded in all calculations of relationship strength.

${ }^{11}$ Let us clarify this with an example. Let an acquiring firm have 3 prior transactions in the four years prior to the announcement of the merger. Two are debt issues for $\$ 100$ million each and one is a merger transaction for $\$$ 25 million. The merger advisor retained in the current transaction was retained as the lead manager in one debt issue, a manager (but not lead) in one issue and was retained as the merger advisor in the prior merger transaction. Then, the relationship strength measure would be $(100$ (lead in debt $)+50$ (not lead in debt $)+25) /$ $225=0.78$.

${ }^{12}$ An alternate way to define relationship strength is to use only banks that were retained as lead managers. If we use this definition, the definition of the lead bank changes only in 18 out of the 611 cases. Thus, the identity of the lead bank is quite robust to changes in the strength measure.
} 
A bank that gets a higher fraction of the total amount of business that a given client firm generates will have a higher value of relationship strength than other banks that get a lower fraction. Holding the total amount of business constant, the bank with higher relationship strength has a higher level of relationship interaction with the client firm. ${ }^{13}$

\subsubsection{Switching of Advisors}

Finally, with respect to a firm switching advisors, a firm is said to have switched if it chooses a merger advisor who it has not retained in any capacity i.e. in any of its prior debt, equity or merger transactions at any time in the prior four years. ${ }^{14}$

\subsection{Summary statistics}

Figures 1 and 2 graphically depict the variation of percentage fees and the log of the total fee (in $\$$ million) with the log of the transaction value (in $\$$ million). Note that there is a fairly large variation in fees charged, both in absolute and percentage terms for transactions of all sizes. For example, there does not appear to be the type of clustering of fees at a particular percentage fee akin to that obtained in the IPO underwriting market (i.e. $7 \%$ ) by Chen and Ritter (2000).

Table 4 Panel A shows some descriptive statistics for this sample. The average fee for the entire time period is $\$ 3.94$ million and the average transaction value is $\$ 1.37$ billion. Firms switched to a new $\mathrm{M}$ and A advisor with whom they had no relationship (in the past four years) $32 \%$ of the time. This figure is similar to that obtained by Krigman, Shaw and

\footnotetext{
${ }^{13}$ As with the market share variable, the relationship strength variable also accounts for mergers among banks. Thus, an acquiring firm that had a relationship with either Bankers Trust or Wolfensohn prior to their merger would be classified as having a relationship with BT Wolfensohn in years subsequent to the merger between BT and Wolfensohn. We avoid double counting to ensure that the relationship strength measure is always less than or equal to 1 .

${ }^{14}$ A bank that was not a lead manager but a manager in an underwriting was assumed to have had a relationship.
} 
Womack (2000) and James (1992) for underwriting relationships. The incidence of switching does not appear to have increased significantly over this time period. Further, firms' relationship strength with their advisors does not exhibit any striking trend over time. Average relationship strength (see Section 2.3.2) for firms that do not switch lies between 0.6 and 0.7 for most years.

Average percentage fees are $0.70 \%$. In contrast to the reduction of underwriting spreads for debt issues documented by Gande, Puri and Saunders (1999), percentage fees for merger advisory services do not show any reduction over time.

Table 4 Panel B compares the effect of tier of the advisor and switching on total fees paid, percentage fees paid, and the size of the acquiring firm. From column 1, we can see that switching has a strong effect on fees paid. Acquiring firms that switch pay an average fee of $\$ 3.44$ million while those that do not pay an average fee of $\$ 4.18$ million. However, transactions where acquiring firms switch are smaller in size than transactions where they do not. The average transaction size for acquiring firms that switch is $\$ 1.25$ billion. The corresponding value for firms that do not switch is $\$ 1.42$ billion. Thus, percentage fees do not show any such reduction. In fact, percentage fees actually increase for clients that switch (71 basis points versus 70 basis points). This is not surprising given the strong negative correlation between percentage fees and transaction size.

Next, the data are divided based on the number of prior transactions that the acquiring firm had. Since we choose a four-year time frame for measurement of relationships and transactions, it is reasonable to classify firms with four or more transactions in four years (i.e. one or more per year) as frequent transactors and those with less than four transactions as infrequent transactors. Out of the 611 transactions, 223 transactions involved acquiring firms 
that were frequent transactors and the remaining 388 transactions involved acquiring firms that were infrequent transactors. These two sets of firms appear to be quite different in terms of transaction value, size of acquiring firm and total fees paid. The average fee for infrequent transactors is $\$ 2.74$ million while that for frequent transactors is $\$ 6.04$ million. The average market value of acquiring firms that are infrequent transactors is about $\$ 1.5$ billion while it is $\$ 6.7$ billion for frequent transactors.

Acquiring firms that choose bottom tier advisors are also much smaller, in terms of market capitalization, than acquiring firms that choose middle tier advisors or top tier advisors. Also, average transaction size decreases as we go from top tier advisors to bottom tier advisors. These results seem to suggest (not surprisingly) that there is an M and A market segmentation with larger firms primarily choosing top and middle tier advisors and smaller firms choosing bottom tier advisors.

Panel 4C presents cross-tabulations of various qualitative variables of interest. The results in the first part of this panel suggest that we can reject the hypothesis that the tier of the advisor is independent of the transaction frequency. Infrequent transactors choose bottom tier banks with a higher probability than frequent transactors. The second part of this panel reveals that switching is also dependent on whether or not the acquiring firm is a frequent transactors. Frequent transactors switch less (51 out of 223 times) relative to infrequent transactors (146 out of 388 times) consistent with the importance of long-term relationship effects among frequent transactors and their principal advisors.

\subsection{Multivariate tests}

Tables 5A and $\mathrm{B}$ show the results of OLS regressions of $\log$ of the total merger advisory fees (Table 5A) and the merger fee percent (Table 5B) on different transaction 
characteristics. All OLS estimates include the White correction for heteroscedasticity. The OLS models were first estimated without any fixed effects and then with fixed effects for the year of the merger announcement and industry classification of the target based on its two digit SIC code. Likelihood ratio tests comparing models with and without fixed effects, suggest that the fixed effects model has a greater explanatory power than the model without fixed effects (at the 1\% level of significance). Therefore, fixed effect dummy variables for industry and year of announcement are included in all regressions. ${ }^{15}$

In what follows, we concentrate on the level of fee results since in virtually all cases, the percentage fees results are consistent with those found using the levels. Moreover, McLaughlin (1992) also concentrated on explaining fee levels. The fit of the regression model in Table $5 \mathrm{~A}$ is reasonably good with an $\mathrm{R}^{2}$ of about $72 \%$. The coefficient of the log of the transaction value is positive and significant indicating that larger transactions have higher fees in absolute terms. The duration of time (in months) between the announcement date of a merger and the completion date also has a positive effect on fees paid. Similarly, the tender offer dummy has a positive effect on fees paid. However, the dummy for a hostile deal is not statistically significant. The number of advisors retained has a positive effect on fees while dummy variables for top and middle tier advisors are highly significant and positive. Many of these empirical results corroborate earlier work done by Mclaughlin (1992) and Hunter and Walker (1990).

With respect to relationships and switching which is the major focus of this paper, Model 1 in Table 5A suggests that switching (proxied by a switching dummy) reduces the level of fees by about $22 \%$ and percentage fees (Table 5B) by about $13 \%$. This implies a

\footnotetext{
${ }^{15}$ The main results are all robust to exclusion of the fixed effect variables.
} 
significant loyalty premium is paid by firms that retain the same $\mathrm{M}$ and $\mathrm{A}$ advisor over time. As noted earlier, this result is consistent with either considerable other relationship benefits accruing to a firm from retaining the same $\mathrm{M}$ and $\mathrm{A}$ advisor (e.g. service efficiency) and/or a material financial cost of switching advisors other than fees paid.

McLaughlin (1992) found that the reputation of an M and A advisor had a strong effect on total fees paid. The univariate results presented earlier confirmed this finding. It is interesting to examine whether the fee benefits of switching vary across the tier or quality of the advisor. To examine this, the switching dummy is interacted with the tier of the advisor (Model 2) in Tables 5A and B. The magnitudes of the coefficients clearly increase as we go from top tier advisors to bottom tier advisors indicating that bottom tier advisors are willing to give a larger fee discount to firms that switch.

Finally, Krigman, Shaw and Womack (2000) found that firms are more likely to switch (for underwriting their seasoned equity offering) to top tier banks if the bank they used at the time of their IPO was not a top tier bank. To further explore this result, we classify firms that switch into three categories - (1) Those that switch to a bank that has the same tier as their current lead bank (lateral switches). (2) Those that switch to a bank that has a higher tier than their current lead bank (upward switches). (3) Those that switch to a bank that has a lower tier than their current lead bank (downward switches). We then compute the fee regressions replacing the single switch dummy with the three switch variables - lateral, upward and downward. The results (Model 3 in Tables 5A and B) indicate that firms that switch downwards appear to get the maximum fee benefit or reduction, while those that switch upwards get the least fee reduction. 
However, the previous results may be biased if the decision to switch is related to any of the independent variables in the OLS regression. The idea can be illustrated by the following example: Say one is able to observe the actual net benefit (cost) of switching or a proxy for this. Denote this by NB. Then, NB as an independent variable in the regression using OLS would capture the marginal effect of the net benefit on fees charged. The problem however is that NB is not observed. Rather, we only observe the actual decision to switch (a dichotomous variable) that is clearly determined by the underlying latent variable NB. In this case, Heckman (1979) has shown that the OLS estimates of the coefficient of switching may be biased.

To account for this effect, one can use the two-stage least squares technique suggested by Heckman (1979) and Greene (1981) to adjust the coefficient estimates and their standard errors. The method involves estimation of a probit model with the switching dummy as the dependent variable. Next, a function of the fitted values of the probability of switching from the first stage probit model is used in a second stage maximum likelihood estimation. We implement this approach using the LIMDEP 7.1 software.

Potentially, transaction and advisor characteristics could have an effect on switching. The probability of switching could also depend on the industry that the target operates in and the year of announcement of the merger (Whether the merger took place during a merger boom or not, etc.). To account for all of these effects, we include all of these variables in the probit estimation model. ${ }^{16}$

\footnotetext{
${ }^{16}$ The method is different in that standard 2SLS used to estimate a system of equations (say supply-demand) which are simultaneously determined. Here, the estimator adjusts for the dependence of other independent variables on the switch dummy. The first stage regression (the probit model) is used to adjust for the dependence of the switch dummy on other independent variables. Therefore, all independent variables can be used in the probit model. If this were a conventional 2SLS, this should not be done, and such a model cannot be estimated.
} 
These results are shown in Table 6A for fee levels and 6B for percentage fees. Again we concentrate the discussion on the fee level regression. The first column in Table 6A displays the results of the first stage (probit model) of the Heckman correction regression. Firms are more likely to switch in tender offers. Consistent with the results in Krigman, Shaw and Womack (2000), firms are also more likely to switch if their lead bank is not a top tier advisor. Frequent transactors are less likely to switch to an unrelated bank. The second column of Table 6A displays the results for the second stage of the Heckman correction regression. The coefficient on the Mill's ratio indicates the significance of this switching dummy. The main result in Tables $6 \mathrm{~A}$ and $\mathrm{B}$ is that switching continues to reduce fees significantly.

While the above results suggest that there may be direct benefits from switching, those firms that do not must perceive direct and indirect benefits from retaining existing relationships. Indeed, an important issue that can be examined is whether these firms that maintain long-term relationships directly benefit through lower fees. That is, does relationship strength (as measured in this paper -- see Section 2.3.2) have a negative effect on the M and A fees paid by the subset of firms that do not switch. If no such direct relationship can be found, it is consistent with relationships providing indirect benefits to firms (i.e. benefits not reflected in lower fees).

Tables 7A Model 1 (for fee levels) and 7B Model 1 (for fee percentage) show that there is no significant effect of relationship strength (for non-switchers) on $\mathrm{M}$ and A fees. Indeed, the coefficient signs are positive but insignificant at the $10 \%$ level. Moreover, even for frequent transactors who don't switch (Model 2 Tables 7A and B), the relationship is insignificant. Finally, Model 3 Tables 7A and 7B examines whether relationship strength is 
more important for firms that use lower tier advisors, i.e., perhaps lower tier advisors are willing to lower fees for non-switchers that have a strong relationship with them. Again, while the coefficients for relationship strength interacted with the advisor tier dummy suggest lower fees for firms loyal to lower tier advisors, the coefficients remain statistically insignificant.

\subsection{Robustness Checks}

Tables 8A and B present some robustness checks of these results. Inclusion of transactions where the acquiring firm had no prior $\mathrm{M}$ and $\mathrm{A}$ or debt or equity transactions does not affect the results of a fee reduction from switching. Likewise, inclusion of transactions where the only role of the advisor was to provide a fairness opinion did not alter the switching results. Interestingly, the no transaction dummy is negative in both cases and significant in the model that includes fairness opinions indicating that banks may give a fee reduction to establish a new relationship with a firm they had no prior relationship with. Moreover, if we define relationship strength using only lead engagements, then this measure has a positive significant effect on fees. Thus, our primary findings, i.e., presence of a switching fee discount (or reduction) and no reduction in fee for a continuing relationship, appear to be robust to different specifications.

\section{4 $\mathrm{M}$ and A Advisors, Relationships and Abnormal Returns}

So far, the analysis has focused on the costs or benefits of an investment banking relationship purely in terms of the fees paid. Clearly, clients could get "indirect" benefits of relationships that are not related to fees. These include (but are not limited to) better quality of service during the merger negotiations, better bargaining with targets, obtaining other services between transactions, etc. Unfortunately, data limitations preclude measurement of many such "indirect" benefits. One possible indirect benefit that is easier to measure is the announcement 
return to the client firm. Specifically, clients that use a relationship bank with experience and knowledge of the client as its $\mathrm{M}$ and $\mathrm{A}$ advisor may provide a more credible signal to the financial markets as to the value-added of a proposed merger transaction than a client who hires, as an $\mathrm{M}$ and $\mathrm{A}$ advisor, a bank with no previous track record with that client. That is, relationship based $\mathrm{M}$ and A advisors may provide valuable "certification" benefits to their clients. ${ }^{17}$ To evaluate these potential certification effects, we calculate abnormal returns for the acquiring firm using a 11-day window [days $(-5,0,+5)]$ around the announcement date of the merger. $^{18}$

Table 9 presents results for univariate tests of the relation between switching and abnormal returns. We classify merger transactions in the sample into those that had positive abnormal returns on the announcement date and those that had negative abnormal returns. We conduct a $\chi^{2}$ of independence between switching and the sign of the abnormal return. We find that these two are independent at conventional levels of significance. The mean abnormal returns present a similar picture. The mean abnormal return for firms that switch is $-0.47 \%$ and for those that do not is $-0.99 \%$. These two values do not differ significantly from each

\footnotetext{
${ }^{17}$ Gande, Puri, Saunders and Walter (1997) and others have found that firms that retain an investment bank with whom they had a prior commercial banking relationship for their debt issues get a higher price for their bonds. Similarly, James and Weir (1990) find that IPO's of firms that had a pre-existing commercial banking relationship are underpriced much less than IPO's of firms that did not have any pre-existing commercial banking relationship.

${ }^{18}$ Sufficient data was not available to estimate the market model for all the acquiring firms. Those firms with less than 240 valid returns in days $(-300,-60)$ are excluded from this analysis. Day 0 is the announcement date of the merger.
} 
other at conventional levels of significance. Therefore, the higher $\mathrm{M}$ and $\mathrm{A}$ fees charged by relationship banks do not appear to be compensation for a higher announcement returns to the acquiring firms' stockholders.

\section{Summary and Conclusions}

This study examined the effects of investment banking relationships on $\mathrm{M}$ and $\mathrm{A}$ advisory fees paid by acquiring firms. We find acquiring firms pay higher fees when they choose a bank with whom they have had a continuing relationship and lower fees when they switch. We find evidence that indicates that reputation of a merger advisor also plays a role in the setting of fees. We developed a measure of the strength of the relationship between an acquiring firm and its merger advisor. Using this variable, we could find no evidence of a relationship discount, i.e. that non-switching firms with long term relationships paid lower M and A fees. These findings are consistent with potential indirect benefits arising from maintaining relationships in the $\mathrm{M}$ and $\mathrm{A}$ market. Examination of merger announcement returns however, indicated no significant difference between acquiring firms that did not switch and those that did. This suggests that acquiring firms accrue some other non-fee related benefits from retaining inside or relationship banks and/or face some other non-pecuniary costs of switching to outside banks. 


\section{References}

Carter, Richard B., Frederick H.Dark, and Ajai K. Singh, 1998, "Underwriter reputation, Initial returns, and the long run performance of IPO stocks," Journal of Finance, Vol. 53, No. 1, 285-311.

Carter, R., and S. Manaster, 1990, "Initial Public Offerings and Underwriter Reputation," Journal of Finance, 45, 1045-1067.

Chen, Hsuan-Chi and Jay R. Ritter, 2000, “The Seven Percent Solution,” Journal of Finance, 55(3), 1105-1131.

Gande, Amar, Manju Puri, and Anthony Saunders, 1999, "Bank Entry, Competition and the Market for Corporate Securities Underwriting," Journal of Financial Economics, 54(2), 165-195.

Gande, Amar, Manju Puri, Anthony Saunders and Ingo Walter, 1997, "Bank Underwriting of Debt Securities: Modern Evidence,” Review of Financial Studies 10(4), 1175-1202.

Greene, William H., 1981, "Sample Selection Bias as a Specification Error: Comment," Econometrica, 49, 795-798.

Heckman, J., 1979, "Sample Selection Bias as a Specification Error,” Econometrica, 47, 153161.

Hunter, William C. and Mary Beth Walker, 1990, “An empirical examination of investment banking merger fee contracts," Southern Economic Journal, 18, 229-252.

James, Christopher, 1992, "Relation-specific assets and the pricing of underwriter services," Journal of Finance, Vol. XLVII, No. 5, 1865-1885.

James, Christopher and Peggy Weir, 1990, "Borrowing relationships, intermediation, and the costs of issuing public securities," Journal of Financial Economics, 28, 149-171.

Krigman, Laurie, Wayne H Shaw and Kent L. Womack, 2000, "Why do firms switch underwriters," forthcoming in Journal of Financial Economics.

McLaughlin, Robyn M., 1990, "Investment-Banking contracts in tender offers - An empirical Analysis," Journal of Financial Economics, 28, 209-232.

McLaughlin, Robyn M., 1992, "Does the form of compensation matter? Investment bankers fee contracts in tender offers," Journal of Financial Economics, 32, 223-260.

Megginson, William L., and Kathleen A. Weiss, 1991, "Venture Capitalist Certification in Initial Public Offerings," Journal of Finance, 46(3), 879-903. 
Nanda, Vikram and Vincent A. Warther, 1998, "The price of loyalty: An empirical analysis of underwriting relationships and fees," University of Michigan working paper.

Rau, P. Raghavendra, 2000, "Investment Bank Market Share, Contingent fee payments, and the performance of Acquiring Firms," Journal of Financial Economics, 56(2), 293324. 
Table 1

Fee Revenue from underwriting and M\&A transactions

This table shows the revenues obtained in 1998 by top commercial and investment banks from underwriting public securities and from merger advising. In calculating fee revenue for public security issues, it is assumed that the lead underwriter earns the entire underwriting spread.

\begin{tabular}{|lllll|}
\hline Investment Bank & $\begin{array}{l}\text { Fee revenue from } \\
\text { public corporate } \\
\text { debt underwriting } \\
\text { (in \$ million) }\end{array}$ & $\begin{array}{l}\text { Fee Revenue } \\
\text { from public } \\
\text { equity } \\
\text { underwriting } \\
\text { (in \$ million) }\end{array}$ & $\begin{array}{l}\text { Fee Revenue } \\
\text { from merger } \\
\text { advice } \\
\text { (in \$ mllion) }\end{array}$ & $\begin{array}{l}\text { Percentage of } \\
\text { Revenue from } \\
\text { merger advice } \\
\text { relative to total } \\
\text { revenue from } \\
\text { public underwriting } \\
\text { and merger advice }\end{array}$ \\
\hline & & & & \\
Morgan Stanley & & & 302.9 & $19.5 \%$ \\
Goldman Sachs & 556.5 & 697.3 & 531.2 & $32.8 \%$ \\
Merrill Lynch & 502.6 & 585.2 & 321.3 & $17.7 \%$ \\
Credit Suisse First Boston & 869.3 & 627.6 & 287.4 & $42.7 \%$ \\
DLJ & 183.2 & 202.8 & 200.0 & $28.9 \%$ \\
Citibank & 188.9 & 302.9 & 189.1 & $17.2 \%$ \\
Lehman & 540.0 & 373.2 & 199.2 & $27.8 \%$ \\
J.P. Morgan & 343.2 & 173.1 & 70.9 & $16.5 \%$ \\
Bankers Trust & 210.9 & 148.0 & 56.9 & $18.4 \%$ \\
NationsBank Montgomery & 60.7 & 191.5 & 26.2 & $16.5 \%$ \\
\hline & 38.0 & 94.7 & & \\
Average (for this sample) & 349.3 & 339.6 & 218.5 & $23.8 \%$ \\
Total (for this sample) & $3,493.3$ & $3,396.3$ & $2,185.1$ & \\
\hline
\end{tabular}

Source: Security Data Company 
Table 2 - Ranking of advisors on market share

This table shows the rank of any advisor that was in the top 10 (in terms of market share) in any year between 1985 and 1998 . In years where the advisor's rank is below 10, the corresponding table entry is blank. Market share is defined as the total dollar value of mergers and acquisitions where the given advisor was retained by the acquiring firm to the total dollar value of all mergers and acquisitions in a given calender year. For mergers where more than one advisor is retained, all advisors are given full credit for the transaction. This table gives credit to the actual subsidiary of the investment or commercial bank that was retained as an advisor and not the parent company.

\begin{tabular}{|c|c|c|c|c|c|c|c|c|c|c|c|c|c|c|}
\hline & 1985 & 1986 & 1987 & 1988 & 1989 & 1990 & 1991 & 1992 & 1993 & 1994 & 1995 & 1996 & 1997 & 1998 \\
\hline Goldman Sachs \& Co & 1 & 1 & 2 & 3 & 4 & 1 & 4 & 1 & 2 & 3 & 2 & 3 & 2 & 1 \\
\hline First Boston Corp & 2 & 3 & 1 & 4 & 8 & 7 & 2 & 5 & & & & & & \\
\hline Morgan Stanley \& Co & 3 & 4 & 4 & 2 & 3 & 2 & 1 & 2 & 3 & 1 & 1 & 2 & 1 & 4 \\
\hline Lazard Freres \& Co LLC & 4 & 7 & & 7 & 5 & & & & 1 & 9 & 9 & 5 & 6 & \\
\hline Merrill Lynch \& Co Inc & 5 & 8 & 7 & & 6 & 3 & 8 & 3 & 5 & 2 & 6 & 1 & 3 & 2 \\
\hline Drexel Burnham Lambert & 6 & 10 & 6 & 6 & & & & & & & & & & \\
\hline Lehman Brothers & 7 & 6 & 3 & 1 & 1 & & 5 & 7 & & 6 & & 6 & 5 & 8 \\
\hline Dillon, Read \& Co Inc & 8 & & & & 9 & 4 & 6 & 6 & & & & & & \\
\hline Kidder Peabody \& Co Inc & 9 & & 8 & 8 & & 9 & & & 7 & 4 & & & & \\
\hline $\begin{array}{l}\text { Salomon Brothers } \\
\text { (Salomon Smith Barney 1998) }\end{array}$ & 10 & 2 & 5 & 5 & 10 & 5 & 3 & 4 & 4 & & 8 & 4 & 4 & 3 \\
\hline PaineWebber & & 5 & & & & 6 & & & & & & & & \\
\hline James D Wolfensohn Inc & & 9 & & & & & 8 & & & & 4 & & & \\
\hline Bear Stearns \& Co Inc & & & 9 & & & & & 10 & 8 & 10 & 3 & 7 & 9 & \\
\hline Prudential-Bache Capital Fund & & & 10 & & & & & & & & & & & \\
\hline Stephens Inc & & & & 9 & & & & & & & & & & \\
\hline Donaldson, Lufkin \& Jenerette & & & & 10 & & & & & 9 & & & & 10 & 6 \\
\hline Wasserstein Perella Group Inc & & & & & 2 & & & & & & & & & \\
\hline Alpine Capital Group & & & & & 7 & & & & & & & & & \\
\hline Furman Selz Mager Dietz Birney & & & & & & 8 & & & & & & & & \\
\hline Alex Brown \& Sons Inc & & & & & & 10 & & & & & & & & \\
\hline Robinson-Humphrey (Old) & & & & & & & 7 & & & & & & & \\
\hline Hellman \& Friedman & & & & & & & 10 & & & & & & & \\
\hline
\end{tabular}

Source: Security Data Company 


\section{Table 2 - Ranking of advisors on market share (continued)}

This table shows the rank of any advisor that was in the top 10 (in terms of market share) in any year between 1985 and 1998. In years where the advisor's rank is below 10, the corresponding table entry is blank. Market share is defined as the total dollar value of mergers and acquisitions where the given advisor was retained by the acquiring firm to the total dollar value of all mergers and acquisitions in a given calender year. For mergers where more than one advisor is retained, all advisors are given full credit for the transaction. This table gives credit to the actual subsidiary of the investment or commercial bank that was retained as an advisor and not the parent company.

\begin{tabular}{|lcccc|}
\hline Bankers Trust Co & 9 & & \\
Smith Barney Shearson & & 6 & 8 & \\
JP Morgan \& Co Inc & 10 & 10 & 8 \\
Gleacher \& Co & & 5 & & 7 \\
Credit Suisse First Boston & & 7 & 5 & 7 \\
Allen \& Co Inc & & 7 & 5 \\
Chase Manhattan Corp & 8 & & \\
Montgomery Securities & & & & \\
NationsBanc Montgomery Sec & & & \\
\hline
\end{tabular}

Source: Security Data Company 
Table 3: Description of variables

This table provides a list of all variables used in the empirical analysis.

\begin{tabular}{|c|c|}
\hline Variable used & Description \\
\hline Log of total merger fees & Log of the absolute fee in $\$$ millions. \\
\hline Fee percentage & Absolute fees expressed as a percentage of the transaction value. \\
\hline Log transaction value & $\begin{array}{l}\text { Log of transaction value which is the total consideration offered to the target in } \$ \text { million. For mergers } \\
\text { involving stock, the stock was valued at the price one day before the announcement date of the merger. }\end{array}$ \\
\hline Duration & Months from the first public announcement date of the merger transaction to completion date. \\
\hline Number of advisors & Variable equal to the number of advisors retained by the acquiring firm for the given merger. \\
\hline Tender offer dummy & Dummy set to 1 if the merger was also associated with a tender offer \\
\hline Hostile bid dummy & Dummy set to 1 if the merger was a hostile bid \\
\hline Switch & $\begin{array}{l}\text { Dummy set to } 1 \text { if the given advisor had not been retained by the acquiring firm in any of its prior } \\
\text { debt, equity or merger transactions in the four years prior to the announcement of the merger. }\end{array}$ \\
\hline Relationship strength & $\begin{array}{l}\text { This is computed by taking the ratio of the total dollar value of issues of debt and equity in which the } \\
\text { merger advisor was the lead manager, half of the dollar value of issues in which the advisor was not lead } \\
\text { manager, but was a manager, and the dollar value of previous merger transactions in which the given } \\
\text { advisor was retained by the acquiring firm to the total dollar value of all debt, equity and merger } \\
\text { transactions by the firm in the previous four years. This measure will always be between } 0 \text { and } 1 \text {. } \\
\text { When a firm switches, relationship strength will be (by definition) equal to zero. In case of mergers between } \\
\text { two merger advisors, all firms that had a relationship with either merger advisor are considered to have a } \\
\text { relationship with the combined entity. See footnote } 11 \text { for an example. }\end{array}$ \\
\hline Lead bank of acquiring firm & The bank that had the highest relationship strength with the acquiring firm. \\
\hline
\end{tabular}


Table 3: Description of variables (continued)

\begin{tabular}{|c|c|}
\hline Variable Used & Description \\
\hline Market Share of advisor & $\begin{array}{l}\text { The ratio of the total } \$ \text { value of transactions where any acquiring firm retained the given merger advisor in an advisory } \\
\text { capacity in a given year to the total } \$ \text { value of all mergers in that year. }\end{array}$ \\
\hline Top tier advisor dummy & $\begin{array}{l}\text { Dummy set to } 1 \text { if the investment bank ranked 1-5 in M\&A market share computation in the calendar year prior to the } \\
\text { announcement of the merger. }\end{array}$ \\
\hline Medium tier advisor dummy & $\begin{array}{l}\text { Dummy set to } 1 \text { if the investment bank ranked 6-20 in M\&A market share computation in the calendar year prior to the } \\
\text { announcement of the merger. }\end{array}$ \\
\hline Tier of advisor & $\begin{array}{l}\text { Integer variable that takes a value of } 0 \text { if the advisor retained by the acquiring firm was a top tier bank, } \\
1 \text { if the advisor retained was a middle tier bank and } 2 \text { if the advisor retained was a bottom tier bank. }\end{array}$ \\
\hline Tier of lead bank & $\begin{array}{l}\text { Integer variable that takes a value of } 0 \text { if the lead bank of the acquiring firm was a top tier bank, } \\
1 \text { if the lead bank was a middle tier bank and } 2 \text { if the lead bank was a bottom tier bank. }\end{array}$ \\
\hline Market Value of the acquiring firm & Market value of equity of the acquirer one month prior to the announcement date of the merger. \\
\hline Number of Transactions & $\begin{array}{l}\text { Total Number of capital market transactions (debt, equity or mergers) completed by the acquiring firm in the four } \\
\text { years prior to the announcement of the merger. }\end{array}$ \\
\hline Frequent transactor & An acquiring firm that had four or more transactions in the four years prior to the announcement of the merger. \\
\hline Infrequent transactor & An acquiring firm that had less than four transactions in the four years prior to the announcement of the merger. \\
\hline Downward switch & Dummy set to 1 when the acquiring firm switched to a merger advisor that had a lower tier than its previous lead bank. \\
\hline Upward switch & Dummy set to 1 when the acquiring firm switched to a merger advisor that had a higher tier than its previous lead bank. \\
\hline Lateral switch & Immy set to 1 when the acquiring firm switched to a merger advisor that had the same tier as its previous lead bank. \\
\hline
\end{tabular}


Figure 1: Percentage fees vs log of Transaction Value

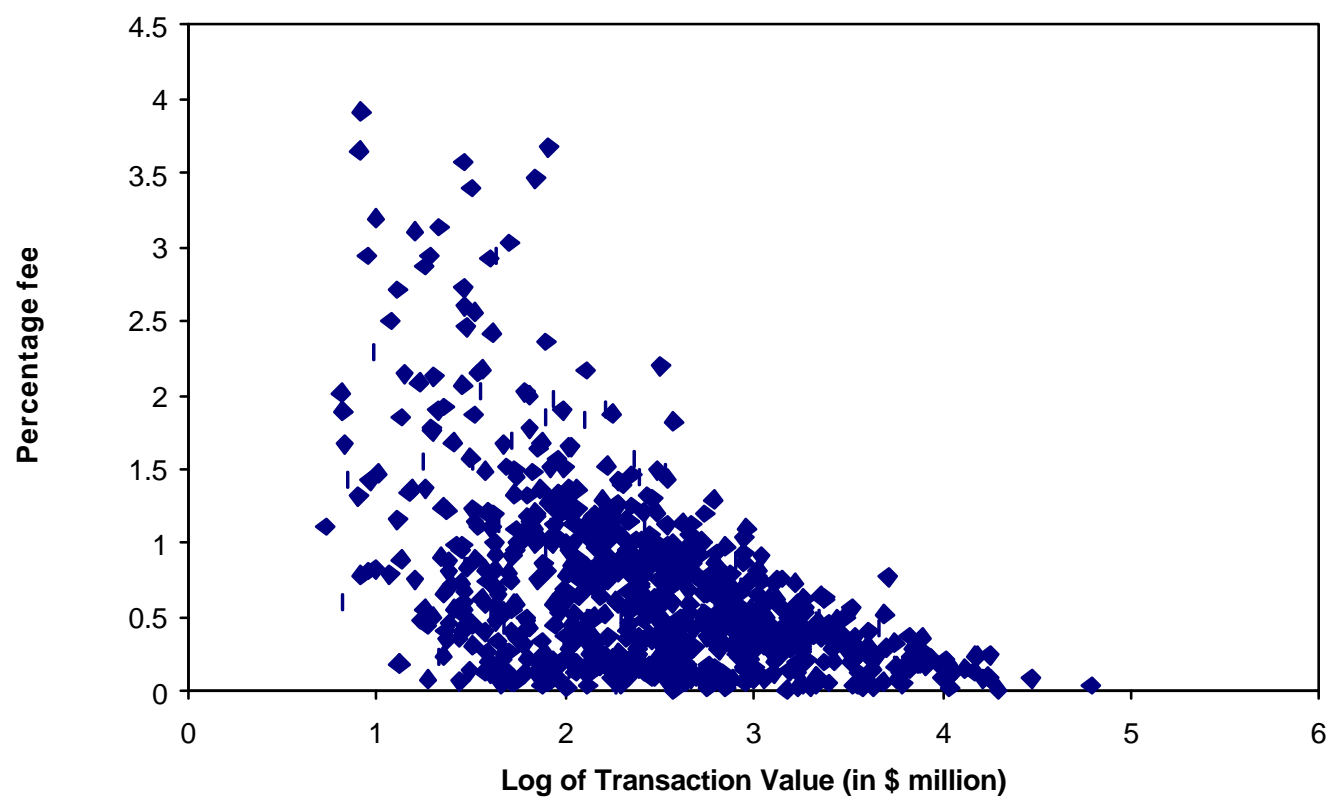

Figure 2 : Log of Total fees vs log of Transaction Value

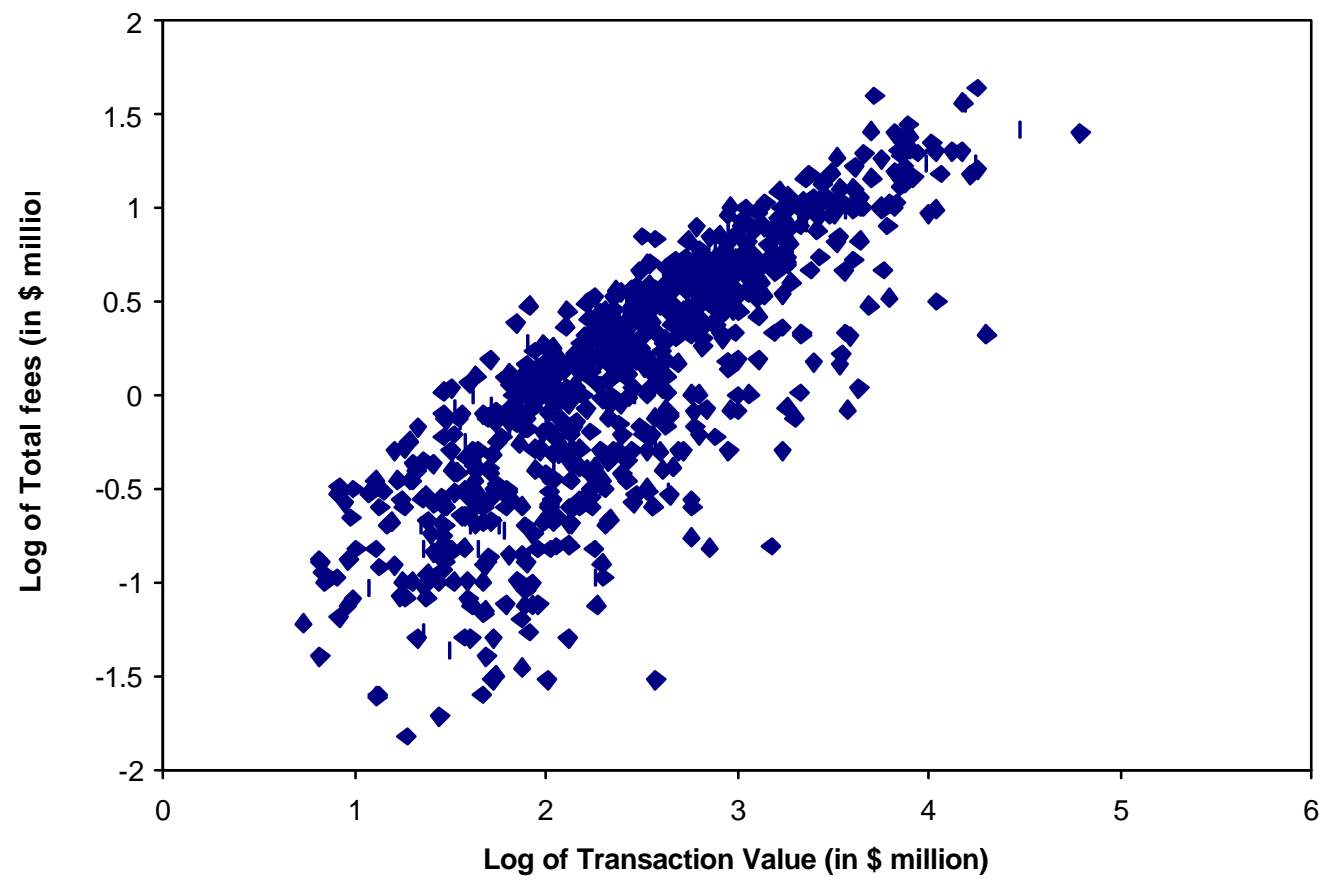




\section{Table 4 Panel A - Summary Statistics}

This panel shows summary statistics for the sample used for empirical analysis in this paper. All absolute dollar values are converted into 1998 dollars using the chain weighted GDP deflator. See Table 3 and Sections 2.3.1, 2.3.2 and 2.3.3 for a desciption of the variables.

\begin{tabular}{|c|c|c|c|c|c|c|c|c|}
\hline Year & $\begin{array}{l}\text { Total Fees } \\
\text { (in \$ million) }\end{array}$ & $\begin{array}{l}\text { Percentage } \\
\text { fees }\end{array}$ & $\begin{array}{l}\text { Transaction } \\
\text { Value } \\
\text { (in \$ million) }\end{array}$ & $\begin{array}{l}\text { Market Value of } \\
\text { Acquiring firm } \\
\text { (in \$ million) }\end{array}$ & $\begin{array}{l}\text { Number } \\
\text { of transactions } \\
\text { where firms switched }\end{array}$ & $\begin{array}{l}\text { Percentage of } \\
\text { transactions where } \\
\text { firms switched }\end{array}$ & $\begin{array}{l}\text { Relationship } \\
\text { strength } \\
\text { (for subset of firms } \\
\text { that did not switch) }\end{array}$ & $\begin{array}{l}\text { Number of } \\
\text { Observations }\end{array}$ \\
\hline All years & 3.94 & 0.70 & 1370 & 3383 & 197 & $32 \%$ & 0.67 & 611 \\
\hline 1985 & 7.87 & 0.35 & 3481 & 3823 & 1 & $9 \%$ & 0.62 & 11 \\
\hline 1986 & 3.64 & 0.75 & 923 & 1949 & 13 & $35 \%$ & 0.67 & 37 \\
\hline 1987 & 3.09 & 0.47 & 822 & 2839 & 8 & $24 \%$ & 0.65 & 33 \\
\hline 1988 & 3.95 & 0.72 & 1452 & 7177 & 8 & $31 \%$ & 0.60 & 26 \\
\hline 1989 & 7.24 & 0.66 & 2306 & 2853 & 7 & $29 \%$ & 0.74 & 24 \\
\hline 1990 & 3.32 & 0.57 & 1157 & 2865 & 3 & $33 \%$ & 0.61 & 9 \\
\hline 1991 & 3.64 & 0.77 & 853 & 1854 & 5 & $29 \%$ & 0.62 & 17 \\
\hline 1992 & 1.96 & 0.84 & 482 & 1052 & 13 & $54 \%$ & 0.64 & 24 \\
\hline 1993 & 2.06 & 0.71 & 824 & 1392 & 4 & $11 \%$ & 0.70 & 37 \\
\hline 1994 & 2.51 & 0.70 & 629 & 1471 & 18 & $38 \%$ & 0.59 & 47 \\
\hline 1995 & 3.48 & 0.76 & 1245 & 3140 & 27 & $36 \%$ & 0.71 & 74 \\
\hline 1996 & 3.61 & 0.66 & 1052 & 5670 & 20 & $29 \%$ & 0.66 & 70 \\
\hline 1997 & 4.36 & 0.72 & 1373 & 3302 & 34 & $33 \%$ & 0.70 & 103 \\
\hline 1998 & 5.23 & 0.73 & 2431 & 4355 & 36 & $36 \%$ & 0.66 & 99 \\
\hline
\end{tabular}




\section{Table 4 Panel B- Univariate comparisons}

Panel B makes univariate comparisons of total fees, percentage fees, transaction value, market value of the acquiring firm with respect to three qualitative variables - (1) transactions where acquiring firms switched and where they did not (2) transactions where the acquiring firms were frequent transactors (had 4 or more transactions in the four years prior to the announcement of the merger) and transactions where the acquiring firms were infrequent transactors (had less than four transactions in the four years prior to the announcement of the merger) (3) transactions where the acquiring firms chose top, middle and bottom tier advisors.

\begin{tabular}{|c|c|c|c|c|c|}
\hline & $\begin{array}{l}\text { Total Fees } \\
\text { (in \$ million) }\end{array}$ & $\begin{array}{l}\text { Percentage } \\
\text { fees }(\%)\end{array}$ & $\begin{array}{l}\text { Transaction } \\
\text { Value } \\
\text { (in \$ million) }\end{array}$ & $\begin{array}{l}\text { Market Value of } \\
\text { Acquiring firm } \\
\text { (in } \$ \text { million) }\end{array}$ & $\begin{array}{l}\text { Number of } \\
\text { Observations }\end{array}$ \\
\hline Acquiring firms that did not switch & 4.18 & 0.70 & 1,426 & 3,460 & 414 \\
\hline Acquiring firms that switched & 3.44 & 0.71 & 1,253 & 3,221 & 197 \\
\hline Acquiring firms were infrequent transactors & 2.74 & 0.79 & 609 & 1,475 & 388 \\
\hline Acquiring firms were frequent transactors & 6.04 & 0.54 & 2,694 & 6,703 & 223 \\
\hline Acquiring firms that chose top tier advisors & 5.82 & 0.65 & 2,155 & 4,312 & 200 \\
\hline Acquiring firms that chose middle tier advisors & 4.17 & 0.66 & 1,350 & 4,069 & 232 \\
\hline Acquiring firms that chose bottom tier advisors & 1.55 & 0.82 & 519 & 1,454 & 179 \\
\hline
\end{tabular}




\section{Table 4 Panel C- Cross Tabulations}

Panel $\mathrm{C}$ presents cross tabulation results between tier of the advisor and the dummy for frequent transactors and between the dummy for switching and the dummy for frequent transactors. An acquiring firm was classified as a frequent transactor if it had four or more transactions in the four years prior to the announcement of the merger. If the acquiring firm had less than four transactions in the four years prior to the announcement of the merger, it was classified as an infrequent transactor.

\begin{tabular}{|c|c|c|c|c|}
\hline & $\begin{array}{l}\text { Acquiring firms } \\
\text { that chose } \\
\text { top tier } \\
\text { advisors }\end{array}$ & $\begin{array}{l}\text { Acquiring firms } \\
\text { that chose } \\
\text { middle tier } \\
\text { advisors }\end{array}$ & $\begin{array}{l}\text { Acquiring firms } \\
\text { that chose } \\
\text { bottom tier } \\
\text { advisors }\end{array}$ & Total \\
\hline Acquiring firms were infrequent transactors & 114 & 132 & 142 & 388 \\
\hline Acquiring firms were frequent transactors & 86 & 100 & 37 & 223 \\
\hline Total & 200 & 232 & 179 & 611 \\
\hline \multicolumn{5}{|c|}{$\begin{array}{l}\text { Test for independence of dummy for frequent transactor and advisor tier } \\
\text { Value of } \chi^{2}(2) \text { Statistic }=27.36 \text {, pvalue }=0.00\end{array}$} \\
\hline & $\begin{array}{l}\text { Acquiring firms } \\
\text { that did not } \\
\text { switch }\end{array}$ & $\begin{array}{l}\text { Acquiring firms } \\
\text { that did } \\
\text { switch }\end{array}$ & & Total \\
\hline Acquiring firms were infrequent transactors & 242 & 146 & & 388 \\
\hline Acquiring firms were frequent transactors & 172 & 51 & & 223 \\
\hline Total & 414 & 197 & & 611 \\
\hline
\end{tabular}


Table 5 A - Effect of switching on merger fees

Estimates of OLS regressions to estimate the impact of switching on merger fees. The dependent variable is the log of the total fees paid. Fixed effect dummies for the target's 2 digit SIC code and the year of announcement are included in the models but not included in the table to conserve space. All variables relating to prior transactions and relationship with the investement bank use a four year period prior to the announcement of the merger transaction. Coefficient estimates and their p-values are reported. Standard errors include the White correction for heteroscedasticity.The switch dummy takes a value of 1 when the acquiring firm chose a merger advisor with whom it had no prior relationship. An upward switch is one where the acquiring firm chose a merger advisor that had a higher tier than its previous lead bank. A lateral switch is one where the acquiring firm chose a merger advisor that had the same tier as its previous lead bank. A downward switch is one where the acquiring firm chose a merger advisor that had a lower tier than its previous lead bank.

\begin{tabular}{|c|c|c|c|c|c|c|}
\hline \multirow[t]{3}{*}{ Independent Variables } & \multicolumn{6}{|c|}{ Dependent Variable is log of total merger fees } \\
\hline & \multicolumn{2}{|c|}{ Model 1} & \multicolumn{2}{|c|}{ Model 3} & \multicolumn{2}{|c|}{ Model 4} \\
\hline & Coefficient & $\mathrm{p}$-value & Coefficient & p-value & Coefficient & p-value \\
\hline Intercept & -3.642 & 0.000 & -3.619 & 0.000 & -3.656 & 0.000 \\
\hline Log transaction value & 0.624 & 0.000 & 0.625 & 0.000 & 0.628 & 0.000 \\
\hline Duration & 0.026 & 0.018 & 0.026 & 0.027 & 0.026 & 0.018 \\
\hline Tender offer dummy & 0.273 & 0.000 & 0.273 & 0.001 & 0.279 & 0.000 \\
\hline Hostile bid dummy & -0.056 & 0.671 & -0.053 & 0.744 & -0.051 & 0.699 \\
\hline Number of advisors & 0.311 & 0.000 & 0.309 & 0.001 & 0.309 & 0.000 \\
\hline Top tier advisor dummy & 0.418 & 0.000 & 0.366 & 0.000 & 0.385 & 0.000 \\
\hline Medium tier advisor dummy & 0.308 & 0.000 & 0.282 & 0.004 & 0.302 & 0.000 \\
\hline Switch dummy & -0.224 & 0.001 & & & & \\
\hline Switch to a top tier bank & & & -0.135 & 0.251 & & \\
\hline Switch to a middle tier bank & & & -0.234 & 0.028 & & \\
\hline Switch to a bottom tier bank & & & -0.290 & 0.009 & & \\
\hline Upward switch & & & & & -0.142 & 0.247 \\
\hline Lateral switch & & & & & -0.218 & 0.006 \\
\hline Downward Switch & & & & & -0.367 & 0.008 \\
\hline $\mathrm{p}$ value of overall regression & 0.00 & & 0.00 & & 0.00 & \\
\hline Sample size & 611 & & 611.00 & & 611 & \\
\hline Pseudo $R^{2} /$ Adjusted $R^{2}$ & $72.32 \%$ & & $72.27 \%$ & & $72.30 \%$ & \\
\hline
\end{tabular}


Table 5 B - Effect of switching on merger fees

Estimates of OLS regressions to estimate the impact of switching on merger fees. The dependent variable is the total fees paid as a percentage of transaction value. Fixed effect dummies for the target's 2 digit SIC code and the year of announcement are included in the models but not included in the table to conserve space. All variables relating to prior transactions and relationships with the investement bank use a four year period prior to the announcement of the merger transaction. Coefficient estimates and their p-values are reported. Standard errors include the White correction for heteroscedasticity.The switch dummy takes a value of 1 when the acquiring firm chose a merger advisor with whom it had no prior relationship. An upward switch is one where the acquiring firm chose a merger advisor that had a higher tier than its previous lead bank. A lateral switch is one where the acquiring firm chose a merger advisor that had the same tier as its previous lead bank. A downward switch is one where the acquiring firm chose a merger advisor that had a lower tier than its previous lead bank.

\begin{tabular}{|c|c|c|c|c|c|c|}
\hline \multirow[t]{3}{*}{ Independent Variables } & \multicolumn{6}{|c|}{ Dependent Variable is merger fees as a percentage of transaction value } \\
\hline & \multicolumn{2}{|c|}{$\begin{array}{ll}\text { Model } 1 \\
\end{array}$} & \multicolumn{2}{|c|}{ Model 2} & \multicolumn{2}{|c|}{ Model 3} \\
\hline & Coefficient & p-value & Coefficient & p-value & Coefficient & p-value \\
\hline Intercept & 3.254 & 0.000 & 3.277 & 0.000 & 3.241 & 0.000 \\
\hline Log transaction value & -0.715 & 0.000 & -0.718 & 0.000 & -0.713 & 0.000 \\
\hline Square of log transaction value & 0.038 & 0.000 & 0.038 & 0.000 & 0.038 & 0.000 \\
\hline Duration & 0.022 & 0.020 & 0.022 & 0.004 & 0.022 & 0.003 \\
\hline Tender offer dummy & 0.144 & 0.014 & 0.143 & 0.007 & 0.147 & 0.005 \\
\hline Hostile bid dummy & -0.038 & 0.539 & -0.035 & 0.735 & -0.037 & 0.726 \\
\hline Number of advisors & 0.112 & 0.018 & 0.110 & 0.057 & 0.112 & 0.053 \\
\hline Top tier advisor dummy & 0.256 & 0.000 & 0.219 & 0.001 & 0.244 & 0.000 \\
\hline Medium tier advisor dummy & 0.195 & 0.000 & 0.186 & 0.003 & 0.192 & 0.000 \\
\hline Switch dummy & -0.133 & 0.001 & & & & \\
\hline Switch to a top tier bank & & & -0.058 & 0.440 & & \\
\hline Switch to a middle tier bank & & & -0.157 & 0.020 & & \\
\hline Switch to a bottom tier bank & & & -0.171 & 0.016 & & \\
\hline Upward switch & & & & & -0.117 & 0.162 \\
\hline Lateral switch & & & & & -0.116 & 0.017 \\
\hline Downward Switch & & & & & -0.231 & 0.011 \\
\hline $\mathrm{p}$ value of overall regression & 0.00 & & 0.00 & & 0.00 & \\
\hline Sample size & 611 & & 611.00 & & 611 & \\
\hline Pseudo $\mathrm{R}^{2} /$ Adjusted $\mathrm{R}^{2}$ & $46.83 \%$ & & $46.78 \%$ & & $46.84 \%$ & \\
\hline
\end{tabular}


Table 6 A - Two stage least squares estimates for effect of switching on merger fees

Estimates of Heckman's 2 stage least squares procedure to estimate the impact of switching investment banks on merger fees. The first column represents the result of a probit regression using the switch dummy as the dependent variable. This dummy variable takes a value of 1 if the acquiring firm retained a merger advisor with whom it had no prior relationship. The second model represents the second stage regression where the dependent variable is the log of the total merger advisory fees paid. Fixed effect dummies for target's 2-digit SIC code and year of announcement are included in both the first and the second stage regressions but not reported in the Table to conserve space. All variables relating to prior transactions and relationship with the investment bank use a 4-year period prior to the merger transaction. Coefficient estimates and their p-values are reported.

\begin{tabular}{|c|c|c|c|c|}
\hline \multirow[t]{2}{*}{ Independent Variables } & \multicolumn{2}{|c|}{$\begin{array}{l}\text { First stage Probit model } \\
\text { Dependent variable is } \\
\text { Switch Dummy }\end{array}$} & \multicolumn{2}{|c|}{$\begin{array}{l}\text { Second stage corrected regression } \\
\text { Dependent variable is } \\
\text { log of total merger fee }\end{array}$} \\
\hline & Coefficient & p-value & Coefficient & p-value \\
\hline Intercept & -0.8427 & 0.0325 & -3.7364 & 0.0000 \\
\hline Log transaction value & 0.0078 & 0.8576 & 0.6268 & 0.0000 \\
\hline Duration & 0.0514 & 0.0227 & 0.0228 & 0.0445 \\
\hline Tender offer dummy & 0.3474 & 0.0285 & 0.2546 & 0.0016 \\
\hline Hostile bid dummy & -0.0491 & 0.8725 & -0.0573 & 0.7206 \\
\hline Number of advisors & 0.0377 & 0.8285 & 0.3089 & 0.0004 \\
\hline Tier of advisor & 0.0996 & 0.2435 & & \\
\hline Tier of lead bank & 0.1655 & 0.0514 & & \\
\hline Dummy for frequent transactor & -0.3349 & 0.0117 & & \\
\hline Top tier Advisor & & & 0.4407 & 0.0000 \\
\hline Middle Tier Advisor & & & 0.3209 & 0.0000 \\
\hline Mill's Ratio & & & -0.1364 & 0.0003 \\
\hline $\mathrm{p}$ value of overall regression & 0.00 & & 0.00 & \\
\hline Sample size & 611 & & 611 & \\
\hline Pseudo $\mathrm{R}^{2}$ / Adjusted $\mathrm{R}^{2}$ & $9.89 \%$ & & $72.33 \%$ & \\
\hline
\end{tabular}


Table 6 B - Two stage least squares estimates for effect of switching on merger fees

Estimates of Heckman's 2 stage least squares procedure to estimate the impact of switching investment banks on the merger fees. The first column represents the result of a probit regression using the switching dummy as the dependent variable. This dummy variable takes a value of 1 if the acquiring firm uses a merger advisor with whom it had no prior relationship. The second model represents the second stage regression where the dependent variable is the merger fee as a percentage of transaction value.

Fixed effect dummies for target's 2-digit SIC code and year of announcement are included in both the first and the second stage regressions but not reported in the Table to conserve space. All variables relating to prior transactions and relationship with the investment bank use a 4-year period prior to the merger transaction. Coefficient estimates and their p-values are reported.

\begin{tabular}{|l|l|l|l|}
\hline \multirow{2}{*}{ Independent Variables } & \multicolumn{2}{|l|}{$\begin{array}{l}\text { First stage Probit model } \\
\text { Dependent variable is }\end{array}$} & \multicolumn{2}{l|}{$\begin{array}{l}\text { lecond stage corrected regression } \\
\text { Sependent variable is } \\
\text { Switch Dummy }\end{array}$} \\
\hline merger fees as a percentage of transaction value
\end{tabular}


Table 7 A- Effect of Relationship strength on merger fees

Estimates of OLS regressions to estimate the impact of relationship strength on merger fees. The dependent variable is the $\log$ of the total merger fees. Fixed effect dummies for the target 2 digit SIC and the year of announcement are included in the models but not included in the table to conserve space. All variables relating to prior transactions and relationship with the investement bank use a four year period prior to the announcement of the merger transaction. Coefficient estimates and their p-values are reported. Standard errors include the White Correction for heteroscedasticity. The sub-sample used in this table consists of transactions where the acquiring firm did not switch, that is, transactions where the acquiring firm chose a merger advisor with whom it has a prior relationship before the merger.

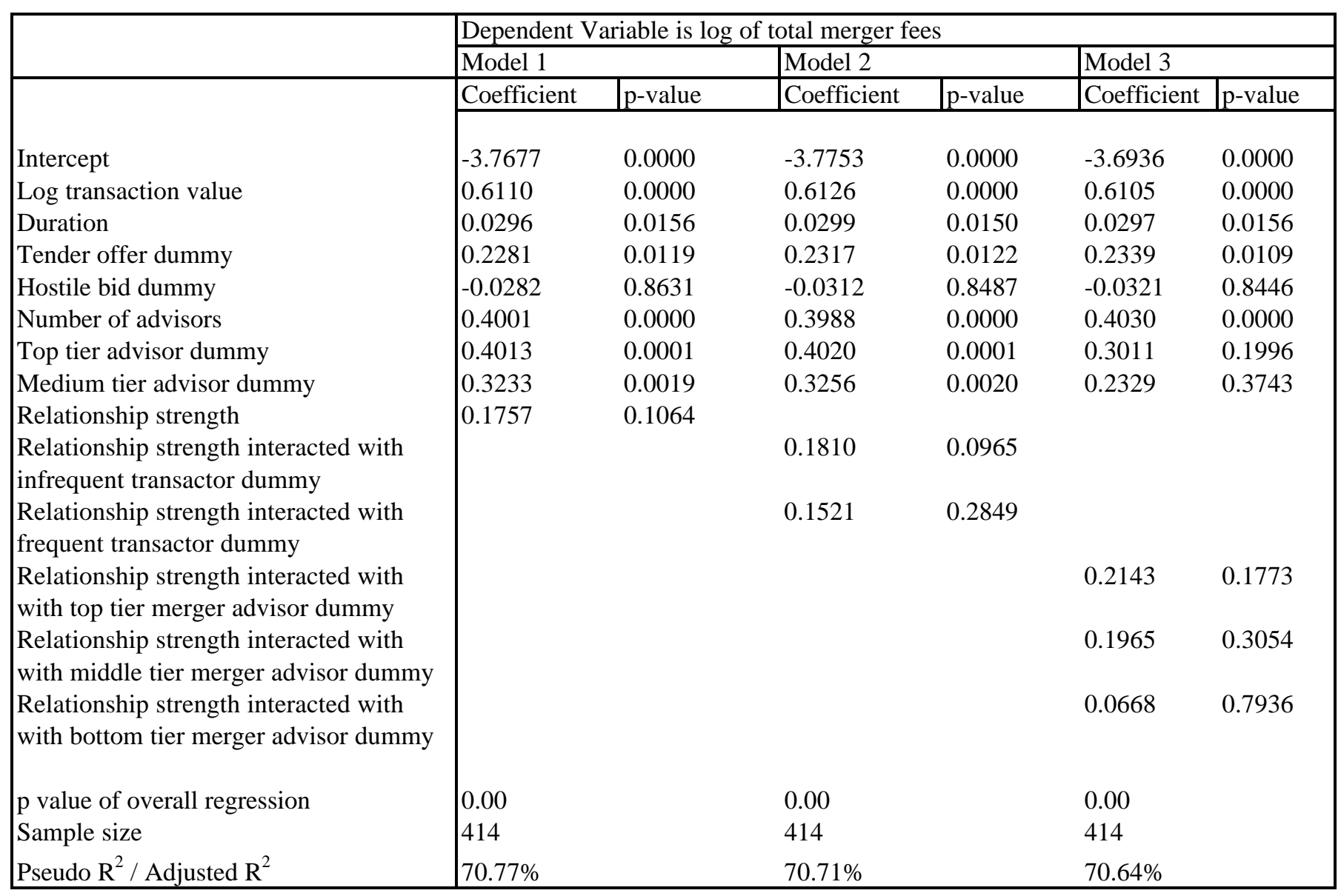


Table 7 B- Effect of Relationship strength on merger fees

Estimates of OLS regressions to estimate the impact of relationship strength on merger fees. The dependent variable is the merger fees as a percentage of transaction value. Fixed effect dummies for the target 2 digit SIC and the year of announcement are included in the models but not included in the table to conserve space. All variables relating to prior transactions and relationship with the investement bank use a four year period prior to the announcement of the merger transaction. Coefficient estimates and their p-values are reported. Standard errors include the White Correction for heteroscedasticity. The sub-sample used in this table consists of transactions where the acquiring firm did not switch, that is, transactions where the acquiring firm chose a merger advisor with whom it has a prior relationship before the merger

\begin{tabular}{|c|c|c|c|c|c|c|}
\hline & \multicolumn{6}{|c|}{ Dependent Variable is the merger fees as a percentage of transaction value } \\
\hline & \multicolumn{2}{|c|}{ Model 1} & \multicolumn{2}{|c|}{ Model 2} & \multicolumn{2}{|c|}{ Model 3} \\
\hline & Coefficient & p-value & Coefficient & p-value & Coefficient & Tp-value \\
\hline Intercept & 3.4946 & 0.0000 & 3.5066 & 0.0000 & 3.6838 & 0.0000 \\
\hline Log transaction value & -0.8094 & 0.0000 & -0.8175 & 0.0000 & -0.8267 & 0.0000 \\
\hline Square of Log transaction value & 0.0441 & 0.0000 & 0.0452 & 0.0000 & 0.0455 & 0.0000 \\
\hline Duration & 0.0222 & 0.0476 & 0.0228 & 0.0419 & 0.0224 & 0.0508 \\
\hline Tender offer dummy & 0.0880 & 0.1687 & 0.1002 & 0.1259 & 0.1009 & 0.1181 \\
\hline Hostile bid dummy & 0.0155 & 0.8495 & 0.0051 & 0.9490 & 0.0087 & 0.9156 \\
\hline Number of advisors & 0.1815 & 0.0001 & 0.1762 & 0.0002 & 0.1887 & 0.0001 \\
\hline Top tier advisor dummy & 0.2538 & 0.0005 & 0.2575 & 0.0004 & 0.0335 & 0.8026 \\
\hline Medium tier advisor dummy & 0.2234 & 0.0006 & 0.2322 & 0.0005 & 0.0701 & 0.5962 \\
\hline Relationship strength & 0.0042 & 0.9466 & & & & \\
\hline $\begin{array}{l}\text { Relationship strength interacted with } \\
\text { infrequent transactor dummy }\end{array}$ & & & 0.0228 & 0.7293 & & \\
\hline $\begin{array}{l}\text { Relationship strength interacted with } \\
\text { frequent transactor dummy }\end{array}$ & & & -0.0738 & 0.2985 & & \\
\hline $\begin{array}{l}\text { Relationship strength interacted with } \\
\text { with top tier merger advisor dummy }\end{array}$ & & & & & 0.1181 & 0.2664 \\
\hline $\begin{array}{l}\text { Relationship strength interacted with } \\
\text { with middle tier merger advisor dummy }\end{array}$ & & & & & 0.0091 & 0.9200 \\
\hline $\begin{array}{l}\text { Relationship strength interacted with } \\
\text { with bottom tier merger advisor dummy }\end{array}$ & & & & & -0.21 & 0.15 \\
\hline$p$ value of overall regression & 0.00 & & 0.00 & & 0.00 & \\
\hline Sample size & 414 & & 414 & & 414 & \\
\hline Pseudo $R^{2}$ / Adjusted $R^{2}$ & $51.41 \%$ & & $51.54 \%$ & & $51.59 \%$ & \\
\hline
\end{tabular}




\section{Table 8 A - Robustness checks}

This table explores the robustness of the switching results to inclusion of other data points such as transactions where the acquiring firm had no prior transactions, transactions where the only role of the advisor was to provide a fariness opinion. All results include the White correction for heteroscedasticity.

\begin{tabular}{|c|c|c|c|c|}
\hline \multirow[t]{3}{*}{ Independent Variables } & \multicolumn{4}{|c|}{ Dependent Variable is log of total merger fees } \\
\hline & \multicolumn{2}{|c|}{$\begin{array}{l}\text { Subsample where } \\
\text { acquiring firm had no } \\
\text { prior transactions }\end{array}$} & \multicolumn{2}{|c|}{$\begin{array}{l}\text { Full sample } \\
\text { (include fairness opinion) }\end{array}$} \\
\hline & Coefficient & p-value & Coefficient & p-value \\
\hline Intercept & -3.7287 & 0.0000 & -3.6443 & 0.0000 \\
\hline Log transaction value & 0.6389 & 0.0000 & 0.6235 & 0.0000 \\
\hline Duration & 0.0205 & 0.0125 & 0.0199 & 0.0119 \\
\hline Tender offer dummy & 0.2606 & 0.0001 & 0.2451 & 0.0002 \\
\hline Hostile bid dummy & -0.0187 & 0.8656 & -0.0172 & 0.8780 \\
\hline Number of advisors & 0.3107 & 0.0000 & 0.3219 & 0.0000 \\
\hline Top tier advisor dummy & 0.4388 & 0.0000 & 0.4642 & 0.0000 \\
\hline Medium tier advisor dummy & 0.3387 & 0.0000 & 0.3740 & 0.0000 \\
\hline Switch dummy & -0.2088 & 0.0016 & -0.2126 & 0.0008 \\
\hline No Transaction Dummy & -0.1037 & 0.1542 & -0.1247 & 0.0740 \\
\hline Fairness opinion dummy & & & -1.1155 & 0.0000 \\
\hline $\mathrm{p}$ value of overall regression & 0.00 & & 0.00 & \\
\hline Sample size & 755 & & 817 & \\
\hline Pseudo $R^{2} /$ Adjusted $R^{2}$ & $75.04 \%$ & & $77.34 \%$ & \\
\hline
\end{tabular}


Table 8 B- Robustness checks

This table explores the robustness of the switching results to inclusion of other data points such as transactions where the acquiring firm had no prior transactions, transactions where the only role of the advisor was to provide a fariness opinion. All results include the White correction for heteroscedasticity.

\begin{tabular}{|c|c|c|c|c|}
\hline \multirow[t]{3}{*}{ Independent Variables } & \multicolumn{4}{|c|}{$\begin{array}{l}\text { Dependent Variable is merger fees as percentage of } \\
\text { transaction value }\end{array}$} \\
\hline & \multicolumn{2}{|c|}{$\begin{array}{l}\text { Subsample where } \\
\text { acquiring firm had no } \\
\text { prior transactions }\end{array}$} & \multicolumn{2}{|c|}{$\begin{array}{l}\text { Full sample } \\
\text { (include fairness opinion) }\end{array}$} \\
\hline & Coefficient & p-value & Coefficient & p-value \\
\hline Intercept & 1.9713 & 0.0000 & 1.8733 & 0.0000 \\
\hline Log transaction value & -0.2730 & 0.0000 & -0.2424 & 0.0000 \\
\hline Square of Log transaction value & 0.0024 & 0.2779 & 0.0001 & 0.4820 \\
\hline Duration & 0.0178 & 0.0198 & 0.0165 & 0.0238 \\
\hline Tender offer dummy & 0.1344 & 0.0135 & 0.1344 & 0.0106 \\
\hline Hostile bid dummy & -0.0184 & 0.7539 & -0.0236 & 0.6824 \\
\hline Number of advisors & 0.1778 & 0.0001 & 0.1845 & 0.0000 \\
\hline Top tier advisor dummy & 0.2284 & 0.0000 & 0.2201 & 0.0000 \\
\hline Medium tier advisor dummy & 0.1680 & 0.0005 & 0.1572 & 0.0005 \\
\hline Switch dummy & -0.1119 & 0.0099 & -0.1132 & 0.0060 \\
\hline No Transaction Dummy & 2.3938 & 0.2855 & 0.0522 & 0.5193 \\
\hline Fairness opinion dummy & & & -0.4695 & 0.0000 \\
\hline $\mathrm{p}$ value of overall regression & 0.00 & & 0.00 & \\
\hline Sample size & 755 & & 817 & \\
\hline Pseudo $\mathrm{R}^{2}$ / Adjusted $\mathrm{R}^{2}$ & $40.37 \%$ & & $41.54 \%$ & \\
\hline
\end{tabular}




\section{Table 9 - Effect of switching on announcement returns}

This table examines the impact of switching on announcement returns of acquiring firms. The announcement returns are calculated using a 11 day window (days -5 to +5 ) around the announcement date of the merger or tender offer.

Abnormal returns are calculated by estimating a market model from days -300 to -60 from the date of announcement.

Acquiring firms that did not have valid returns for these 240 days are excluded. This results in a sample of 564 transactions which is then used to examine the impact of switching.

\begin{tabular}{|c|c|c|c|}
\hline $\begin{array}{l}\text { No switch } \\
\text { Switch } \\
\text { Total }\end{array}$ & $\begin{array}{c}\text { Positive return } \\
174 \\
87 \\
76\end{array}$ & $\begin{array}{c}\text { Negative return } \\
205 \\
98 \\
69\end{array}$ & $\begin{array}{c}\text { Total } \\
379 \\
185 \\
564\end{array}$ \\
\hline \multicolumn{4}{|c|}{$\begin{array}{l}\text { Test for independence of switching and the sign of the return } \\
\text { Value of } \chi^{2}(1) \text { Statistic }=0.06 \text {, pvalue }=0.80\end{array}$} \\
\hline & Mean Returns & Median Returns & \\
\hline $\begin{array}{l}\text { No switch } \\
\text { Switch } \\
\text { Total } \\
\text { t statistic for difference in mean } \\
\text { p value (one tail) }\end{array}$ & $\begin{array}{l}-0.99 \% \\
-0.47 \% \\
-0.82 \% \\
-0.56 \\
29 \% \\
\end{array}$ & $\begin{array}{l}-0.84 \% \\
-0.63 \% \\
-0.82 \%\end{array}$ & \\
\hline
\end{tabular}

